The Chapter Headings of the Morte Darthur : Caxton and de Worde

Author(s): James Wade

Source: Modern Philology, Vol. 111, No. 4 (May 2014), pp. 645-667

Published by: The University of Chicago Press

Stable URL: https://www.jstor.org/stable/10.1086/674958

JSTOR is a not-for-profit service that helps scholars, researchers, and students discover, use, and build upon a wide range of content in a trusted digital archive. We use information technology and tools to increase productivity and facilitate new forms of scholarship. For more information about JSTOR, please contact support@jstor.org.

Your use of the JSTOR archive indicates your acceptance of the Terms \& Conditions of Use, available at https://about.jstor.org/terms 


\title{
The Chapter Headings of the Morte Darthur: Caxton and de Worde
}

\author{
JAMES WADE \\ Christ's College, Cambridge
}

\begin{abstract}
Since the discovery of the Winchester Manuscript in 1934, perhaps the most enduring question in Malory criticism has been one of form. Before then, our earliest source for Malory's "hoole book of kyng Arthur \& of his noble knyghtes of the rounde table" was William Caxton's print of $1485,{ }^{1}$ but with new access to an earlier and apparently independent manuscript, the "hoole book" began to look very different. ${ }^{2}$ The major critical fault line in the wake of this find is perhaps best captured by the title of Eugène Vinaver's influential 1947 edition: Works. ${ }^{3}$ By calling into question the unity of
\end{abstract}

1. James W. Spisak, ed., Caxton's Malory, 2 vols. (Berkeley: University of California Press, 1983), 1:599 (21.13). For references to the main text I cite volume and page number, followed by Caxton's corresponding book and chapter number in parentheses. References to Caxton's edition (C) follow the John Rylands Library copy, the full text of which is available on Early English Books Online (EEBO), http://eebo.chadwyck.com, STC 801. The Winchester Manuscript (hereafter W) is now housed in the British Library (Add. MS 59678). The last gathering of $\mathrm{W}$ is wanting, though it seems most likely that the reference to the "hole book" is authentic, given that it immediately precedes a first-person address from "Syr Thomas Maleore, knight." For W there is a print facsimile and Takako Kato's Malory Project website, which contains highresolution color images of the manuscript. See The Winchester Malory, ed. N. R. Ker, EETS, s.s., 4 (1976); The Malory Project, http:/ / maloryproject.com.

2. Vinaver proposed a stemma in which $\mathrm{W}$ and $\mathrm{C}$ are independently derived from an intermediary archetype $(\mathrm{X})$, with additional lost manuscripts $(\mathrm{Y}, \mathrm{Z})$ between $\mathrm{X}$ and $\mathrm{W}$, C. So the W branch: $\mathrm{M}-\mathrm{X}-\mathrm{Y}-\mathrm{W}$; and the $\mathrm{C}$ branch: $\mathrm{M}-\mathrm{X}-\mathrm{Z}-\mathrm{C}$. That $\mathrm{W}$ and $\mathrm{C}$ derive independently from a common intermediary, $\mathrm{X}$, has been more generally accepted, though the $\mathrm{Y}$ and $\mathrm{Z}$ links have been considered much less certain. The identification of corrected eyeskip errors has effectively ruled out the possibility of a linear stemma, $\mathrm{M}-\mathrm{W}-\mathrm{C}$ or $\mathrm{M}-\mathrm{W}-\mathrm{X}-\mathrm{C}$. See The Works of Sir Thomas Malory, ed. Eugène Vinaver, rev. P. J. C. Field, 3rd ed., 3 vols (Oxford: Clarendon, 1990), 1:cvi; also, P. J. C. Field, "Malory and His Scribes," Arthuriana 14 (2004): 3142. Various possible stemmata are also outlined by Shunichi Noguchi, "The Winchester Malory," in The Malory Debate: Essays on the Texts of "Le Morte Darthur," ed. Bonnie Wheeler, Robert L. Kindrick, and Michael N. Salda (Cambridge: Brewer, 2000), 120; and P. J. C. Field, "Caxton's Roman War," in Wheeler, Kindrick, and Salda, Malory Debate, 142.

3. The Works of Sir Thomas Malory, ed. Eugène Vinaver, 3 vols. (Oxford: Clarendon, 1947).

(C) 2014 by The University of Chicago. All rights reserved. 0026-8232/2014/11104-0003 $\$ 10.00$ 
Malory's massive collection of Arthurian tales, Vinaver opened the debate as to what Malory actually wrote and how Caxton and successive editors represented that original text. ${ }^{4}$ What we know from Caxton, and what we knew before 1934, is that Caxton "deuyded" his volume into "xxj books and euery book chapytred," but it is only by looking to the surviving manuscript that we can think about just what sort of inventiveness went into that restructuring. Indeed, there has been substantial attention to the placement of Caxton's book and chapter divisions themselves-where they do or do not correlate with the various levels of division in $\mathrm{W}$-and these inquiries have suggested much about both Caxton's editorial processes and habits, and how form creates meaning in the Morte Darthur. ${ }^{5}$ There has not, however, been a thorough or sustained consideration of the descriptive rubrics or headings Caxton gave to each of his 506 chapters, which Wynkyn de Worde also used in his edition thirteen years later. ${ }^{6}$ Here I want to consider what the headings can tell us about the working practices of these two early editors and how their very different use of these headings has a significant effect on the reading experience.

It was only after Caxton finished printing the main text of the Morte Darthur that he composed and printed his famous prologue and the book and chapter rubrics that are continuous with it. We know this because the prologue and table of contents were printed in separate quires with irregular signatures, and more importantly because the table corrects errors in chapter numbering present in the main text, in which Caxton gives only

4. Derek Brewer was the first to formally oppose Vinaver on the unity question. See D. S. Brewer, “The hoole book,"” in Essays in Malory, ed. J. A. W. Bennett (Oxford: Clarendon, 1963), 41-63; the reading list on the relationship between $W$ and $C$ is extensive; see the bibliography on Kato's Malory Project website, http://maloryproject.com/bibliography.php. In particular, see Lotte Hellinga, "The Malory Manuscript and Caxton," in Aspects of Malory, ed. Toshiyuki Takamiya and Derek Brewer (Cambridge: Brewer, 1981), 127-42; Murray J. Evans, "Ordinatio and Narrative Links: The Impact of Malory's Tales as a 'hoole book," in Studies in Malory, ed. James W. Spisak (Kalamazoo, MI: Medieval Institute Publications, 1985), 29-52; Carol M. Meale, “The Hoole Book': Editing and the Creation of Meaning in Malory's Text," in A Companion to Malory, ed. Elizabeth Archibald and A. S. G. Edwards (Cambridge: Brewer, 1996), 3-17; and see also Wheeler, Kindrick, and Salda, Malory Debate.

5. See N. F. Blake, "Caxton Prepares his Edition of the Morte Darthur," in William Caxton and English Literary Culture (London: Hambledon, 1991), 199-211; Toshiyuki Takamiya, "Chapter Divisions and Page Breaks in Caxton's Morte Darthur," Poetica 45 (1996): 63-78; Meale, "The Hoole Book"; Helen Cooper, "Opening Up the Malory Manuscript," in Wheeler, Kindrick, and Salda, Malory Debate, 255-84; Takako Kato, Caxton's "Morte Darthur": The Printing Process and the Authenticity of the Text (Oxford: Society for the Study of Medieval Languages \& Literature, 2002); D. Thomas Hanks, "Textual Harassment: Caxton, de Worde, and Malory's Morte Darthur," in Re-viewing "Le Morte Darthur": Texts and Contexts, Characters and Themes, ed. K. S. Whetter and Raluca L. Radulescu (Cambridge: Brewer, 2005), 27-47.

6. Spisak (Caxton's Malory, 2:612) points out that Caxton's misnumbering of his chapters results in the claim for one more chapter than he actually has. 
the chapter numbers and not the headings. ${ }^{7}$ It is most likely the case that Caxton read through his copy text to mark out the chapter divisions in the first instance and then went through it again to set the cast-off marks, giving thirty-five lines to pages with chapter divisions and thirty-eight to pages without. ${ }^{8} \mathrm{He}$ did this to appropriate page space for the standard three-line gap and three-line woodblock capital at the chapter breaks. It seems that it would have been unnecessarily cumbersome for him to have composed the descriptive headings in the midst of the casting-off process, and if he had worked through the text a third time before his compositors set the type, he would have likely corrected the mistakes in chapter numbering before they made it to press. ${ }^{9}$ Rather, the more natural explanation is that the headings were what D. Thomas Hanks calls a "printerly afterthought," a supplement to his prologue intended to familiarize potential buyers with the specific contents of his product. ${ }^{10}$ As Caxton puts it, they are included for readers of the prologue (i.e., customers, at least initially) to "vnderstonde bryefly the contente of thys volume."

Here though, Caxton, and Hanks, who says that the table lists "generally what occurs overall in each liber, and specifically the occurrences in each capitulum," might not be wholly accurate in describing what the table contains. ${ }^{11}$ One might expect that these descriptive chapter headings would provide a summary of the events that occur within their given chapters, or at least that they would describe the highlights - their chapters' most significant episodes or occurrences. On the whole, however, this is not the norm. Most of Caxton's headings are front-end heavy, in that they give con-

7. So, for instance, when in bk. 4 the text skips from chap. 18 to chap. 20, with a long passage of unbroken prose where there ought to have been a chapter break, the table of contents gives: "How Syr Marhaws iusted with Syr Gawayn and Syr Ewayn and ouerthrewe them bothe capitulo xviij and xix." Caxton faced a different problem in bk. 7, in which chap. 25 is misnumbered 26 in the main text, with a knock-on effect throughout the rest of the book. To fix this he simply corrected chap. 26 in the main text to chap. 25 in the table, and skipped ahead in the table to chap. 27 , so that in the text and table the numbers of the remaining nine chapters of bk. 7 would accord. The content of $\mathrm{C}$ is distributed as follows: Caxton's prologue, $2 \mathrm{r}-4 \mathrm{r}$; table of contents, $4 \mathrm{v}-32 \mathrm{v}$; main text, alr-ee6r; Caxton's colophon, ee6r. For further details see Spisak, Caxton's Malory, 2:612.

8. For more on this process see Kato, Caxton's “Morte Darthur, " esp. 49-60.

9. Takamiya and, in greater detail, Kato, note how the blank space allocated to the chapter breaks benefited the compositors, in that the extra white space gave them more leeway in setting sheets by formes. Takamiya, "Chapter Divisions and Page Breaks," 68-69; Kato, Caxton's "Morte Darthur," esp. 43-44.

10. Hanks, "Textual Harassment," 32; also, Blake, "Caxton Prepares His Edition of the Morte Darthur," 200-205. Blake notes that while it remains possible that Caxton composed the headings before the main text was in type, "the most natural explanation" is that he did not (200).

11. Hanks, "Textual Harassment," 32. 
siderably more attention to, and often focus entirely on, only the first events that happen in what are often complex and episodic chapters. Certainly Caxton occasionally gives balanced headings such as "How alysaunder mette wyth alys la beale pylgrym / and how he iusted wyth two knyghtes / And after of hym and of Syr Mordred" (10.39), in which each clause accounts for each of the chapter's three episodes; and, similarly, "How the sayd knyght came ageyn the next nyght \& was beheded ageyn / \& how at the feste of pentecost al the knyghtes that Syr gareth had ouercome cam \& yelded hem to kyng arthur" (7.23), in which the virgule signals an interlace division in the main text. Headings such as these, however, are unusual in their comprehensiveness.

Far more common are headings like "How sir Launcelot cam in to the chapel peryllous \& gate there of a dede corps a pyece of the cloth \& a swerde" (6.15), or "How a yonge man came in to the courte of kyng arthur / and how syr Kaye called hym in scorne la cote male tayle" (9.1). In the first, Caxton describes only the initial events (comprising only twenty-three of the chapter's seventy-two lines in C) and fails to mention Lancelot's perhaps more memorable encounter with the sorceress Hallawes, who instigates the adventure to begin with. The heading also omits the chapter's final episode, in which Lancelot heals Sir Melyot with the sword he achieved at the Chapel Perilous. It could be argued that early readers of Malory would have considered this healing of Sir Melyot the most interesting or important event of the chapter, as on folio $110 \mathrm{v}$ in $\mathrm{W}$ there is a marginalium that reads: "Here Sir Launcelot heled sir Melyot de Logyrs with Sir Gylberde pe basterdis swerde." 12 Much the same could be said about the heading for book 9, chapter 1. It describes La Cote Male Taylé's arrival at Arthur's court, and of his naming by Kay, but it leaves out the chapter's second and surely more memorable half, when the new knight saves Guinevere from a "horryble lyon" that suddenly breaks free from a stone tower. Certainly, Caxton may have thought that it is more important in a table of contents to signal the introduction of major characters like La Cote Male Tayle than it is to account for exciting but self-contained and nonintegral events, but the question is not one of why Caxton chose this knight's naming over his battle with the lion, or the Chapel Perilous over the healing of Sir Melyot, but

12. See below for more on the relationship between the chapter headings and W's marginalia. There has been some debate as to the authorship of W's marginalia. P. J. C. Field ("Malory's Own Marginalia," Medium Evum 70 [2001]: 226-39) has argued that most were composed by Malory himself and copied from W's archetype (in this case by scribe B). An alternative theory is that they are the inventions of each scribe, and thus original to W, which has been argued by Helen Cooper ("Opening Up the Malory Manuscript," esp. 268-71) and me (James Wade, "Malory's Marginalia Reconsidered,” Arthuriana 21 [2011]: 70-86). 
rather why his headings are not comprehensive to begin with and why they tend to describe only first events.

The most likely explanation is one of practicality or expediency. A table of contents that describes all episodes or major events in the Morte Darthur would be far longer than the thirty-one pages Caxton devotes to it and would of course have taken far longer to complete. If we consider, too, that this was likely the final task before Caxton would have had the last quires printed and the book bound and put up for sale, it might not be too hard to imagine a mindset of urgency or at least thriftiness. Alternatively, it has been argued that Caxton used the headings to focus the reader's (or prospective buyer's) attention on Arthur. Hanks notes that Arthur's name "appears again and again" in the headings, and those readers who worked through the table would have come to the book proper "with Caxton's view of Arthur's centrality firmly implanted." ${ }^{\text {"13 }}$ Following Hanks, Kevin T. Grimm goes so far as to say that "Caxton shows no interest in Launcelot or in any of the other individual knights" in an attempt to cater to the reader's expectations of a volume on Arthur. ${ }^{14}$ These arguments, however, do not hold with a tally of the chapter headings overall. In a text where names, and renown, are of extraordinary importance, Arthur is only the third most frequently named character in the table: Lancelot is named 152 times, Tristram 132, and Arthur 109 (though compare Gawain at 36 times, and Morgan le Fay at 11). And even in chapters in which Arthur is central to the action, there is no indication that Caxton is going out of his way to include his name in the heading. Take, for example, book 20, chapter 9: "Of the sorowe \& lamentacyon for the dethe of hys neuewes \& other good knyghtes / \& also for the quene his wyf." It is only by going to the text itself, or in considering this heading in the broad context of the table, that a reader could know that the pronouns refer to Arthur. Nor does Caxton appear to have composed the headings according to any other conditioning impulse. Unlike the marginalia in $\mathrm{W}$, which on the whole tend to point the reader to chivalric combats or violent deaths, Caxton's headings hold no significant patterns in terms of characters, themes or event types. ${ }^{15}$ Even Lancelot's and Tristram's dominance in the names league table seems to only be a symptom of the recur-

13. Hanks, "Textual Harassment," 32.

14. Kevin T. Grimm, "Wynkyn de Worde and the Creation of Malory's Morte Darthur," in The Social and Literary Contexts of Malory's “Morte Darthur," ed. D. Thomas Hanks Jr. and Jessica Gentry Brogdon (Cambridge: Brewer, 2000), 137.

15. Field reckons that 83 percent of scribe A's marginalia in his first two stints (and 31 percent in his third) deal with violent combat or death, compared with 85 percent for scribe B. Cooper notes that scribe A has a tendency to focus on dreams, visions and prophecies. See Field, "Malory's Own Marginalia," 229; Cooper, "Opening Up the Malory Manuscript," 26871 . 
rence of their characters, especially in that long swath of text between the end of Gareth's tale and the beginning of the Grail Quest, books 8-12.

If, rather, Caxton did indeed focus largely on first events in composing his headings-presumably on pragmatic grounds-a few more editorial details fall into place. One is the fact that, when collated with $\mathrm{W}$, the headings only rarely correlate directly with the marginalia associated with their given section of text. A good example is the case of book 6, chapter 15, noted above, where the healing of Sir Melyot, highlighted in the marginalium, occurs in the last third of the chapter. But this is a common trend. Of the eighty marginalia in $\mathrm{W}$, forty-two bear no relationship whatsoever to Caxton's headings, and only in the case of two-book 6 , chapter $11,105 \mathrm{v}$, and book 7 , chapter $6,117 \mathrm{v}$-is there a direct verbal correspondence. ${ }^{16}$ Of the remaining thirty-six, where there is at least some shared subject matter (which is what one would expect from bibliographical features with indexical functions), either the marginalia refer to the first (or only) events or episodes of the given chapters, or Caxton's headings are more comprehensive. Helen Cooper has already noted this marked dissimilarity between Caxton's headings and W's marginalia, and my conclusions match hers: that W's marginalia did not appear in Caxton's copy text, and that Caxton did not look to $\mathrm{W}$ (which was likely in his workshop at the same time) when he came to draw up his headings. ${ }^{17}$

Another detail is Caxton's tendency toward lexical repetition. Often he will incorporate key words or phrases from a chapter into its heading. For example, compare the heading

How syr palomydes folowed the questyng beest \& smote doun syr Trystram and syr Lamerock with one spere (9.12)

with the following passage, beginning seven lines below the chapter break,

\& this beest euermore syr palomydes folowed / for hit was called his quest /

\& ryght so as he folowed this beest / it came by syr Tristram / and soone after cam Palamydes / and to breue this matere / he smote doune sir tristram and sir Lamorak bothe with one spere. (1:255 [9.12])

16. For bk. 6, chap. 11, 105v, the heading reads, "How syr launcelot slewe ij geauntes \& made a castel free"; the marginalium, "Here sir Launcelot slew ij Gyauntis in pe castel of tyntagil." For bk. 7, chap. 6, 117v, heading reads, "How beaumayns fought \& slewe ij knyghtes at a passage"; the marginalium, "Here sir Bewmaynes slew ij knyghtes at a passage." In bk. 6, chap. 11 , this is the first event in a long and episodic chapter; in bk. 7, chap. 6, this is both the first and most important event.

17. Cooper, "Opening Up the Malory Manuscript," 271. This argument runs against David Matthews, who argued that Caxton drew on W's marginalia for his headings to bk. 6. See David Matthew, "The Besieged Printer," in Wheeler, Kindrick, and Salda, Malory Debate, 35-64, esp. 54-55. This article first appeared in Arthuriana 7 (1997): 63-92. 
Next, compare the heading

How Syr Percyual for penaunce roof hym self thorugh the thyghe / and how she was knowen for the deuyl (14.10)

with the associated passage, beginning six lines from the start of the chapter,

Thenne syr percyual made grete sorowe / and drewe his suerd vnto hym / saying sythen my flessh will be my maister I shalle punysshe it / and there with he rofe hym self thurgh the thygh that the blood starte aboute hym.

$(1: 456[14.10])$

This technique mimics the verbal texture of Malory's prose, and the repetition conditions readers for moments of recognition, in which we identify key images or moments already signaled in the headings as such. This significance is in part amplified by the absence of other events or details in the headings, but more positively, it is also built up through what Mark Lambert calls "confirmation," or a lexical repetition across multiple levels of discourse. ${ }^{18}$ Lambert is interested in the kind of confirmation that is internal to Malory's prose, but the principle still applies between text and apparatus. Corroboration of this sort works to give the impression of factual accuracy, both for heading and text, and in moving from table to text, the lexical correspondence helps trigger the experience of proleptic knowledge. In other words, readers are reminded of those happenings of which they already knew, and knew to be significant, but now know more fully or more completely in context.

It is unusual in Caxton's Malory, however, to have this sort of confirmation occur at a relative distance from the start of a chapter (six and seven lines in the examples cited above). In most instances where Caxton recreates the verbal texture of his main text, he tends to draw from the chapter's first or second lines. Consider the following three examples, with headings followed by the beginnings of their respective chapters:

Heading: "How at the yeres ende alle thre knyghtes wyth theyr thre damoyselles metten at the fontayne"

Text: "Ryght soo at the twelue monethes ende they mette alle thre knyghtes at the fontayne and their damoisels" (1:120 [4.29])

Heading: "How the lady that was bysyeged had worde fro hyr syster how she had brought a knyght to fight for hyr / and what bataylles he had achyeued"

18. Mark Lambert, Malory: Style and Vision in "Le Morte Darthur" (New Haven, CT: Yale University Press, 1975), 8-16; see also Jeremy Smith, "Language and Style in Malory," in Archibald and Edwards, Companion to Malory, 97-113. 
Text: "Soo the book saith / that the lady that was biseged had word of her systers comynge by the dwerf and a knyghte with her / and how he had passed al the perilous passages" (1:171 [7.14])

Heading: "How there came a voys whyche charged syr bors to touche not hym and of a cloude that came bytwene them"

Text: "And thenne he herd a voyce that sayd flee Bors \& touche hym not / or els thow shal slee hym / Ryght so aly3t a clowde betwixe them in lykenes of a fyre and a merueyllous flame" (1:479 [16.17])

Close verbal echoes of this sort are relatively common in Caxton's edition, occurring in over thirty chapters, though the number would be much higher if we took into account the repetition of short phrases or single key words, such as "on mayeng" in book 9, chapter 1, "How quene Gueneuer rode on mayeng with certeyn knyghtes of the rounde table and clad al in grene." ${ }^{19}$ Such immediate confirmation tightens the relationship between heading and text, so that there is a greater sense of continuity between the Table and the section it describes, especially when the two are many hundred pages away from each other, as is the case with book 19, chapter 1 .

These echoes, too, are part and parcel of Caxton's broader trend of emphasising first events; here summaries of opening episodes have been replaced by paraphrases of first clauses, which on the whole introduce or set the stage for the main action of the chapter, rather than describe it. The conclusions we might draw from this are threefold. First, the experience of moving from table to text is much more haphazard than one might expect. There is no guarantee, that is, that the heading will alert the reader to all the events or episodes in the given chapter, or even alert the reader to that chapter's most interesting or significant happenings. Second, and related to this, Caxton's table is thus not as reliable a finding aid as might be hoped, or expected. In the rhetoric of his prologue Caxton claims that the headings are intended to give an overview of the contents of the whole volume. In practice, however, the headings surely must have been used to locate favorite events or episodes, especially in a fifteenth-century culture of oral household reading, and especially when dealing with a narrative as massive and varied as the Morte Darthur. ${ }^{20}$ But readers looking for the

19. "Clad al in grene" also comes direct from the main text, where seven lines from the chapter head Guinevere asks the knights accompanying her to be "clothed in grene" (1:538 [19.1]).

20. Joyce Coleman (Public Reading and the Reading Public in Late Medieval England and France [Cambridge University Press, 1996], esp. 213) has argued that the earliest texts of Malory's romance were read aloud. Caxton clearly anticipated an audience of both listeners and readers; see Karen Cherewatuk, "Aural and Written Reception in Sir John Paston, Malory, and Caxton," Essays in Medieval Studies 21 (2004): 123-31; and also George Shuffelton, "Is There a Minstrel in the House? Domestic Entertainment in Late Medieval England," Philological Quarterly 87 (2008): 51-76. 
healing of Sir Melyot, the sorceress Hallawes or La Cote Male Taylés battle with the lion will search in vain, as will, for instance, those readers looking for such moments of interest as Lancelot's theft of Kay's armour (6.11), Gareth's first challenge against the six thieves (7.5) or Tristram's marriage to Isode le Blaunche Maynes (8.36). I would not want to suggest that these gaps amount to a major editorial failing by any means, but they do accumulate, and the general effect is one of a consistently inadequate index.

The third conclusion is that Caxton, when he went back to compose the headings, appears to have had no prearranged or overarching strategy for dealing with the multiple and various events his chapters contained. For some chapters he gives comprehensive summaries of all significant events, for others he highlights only the first or second events, and for others still he simply paraphrases the first few lines of the chapter. In these last two instances, too, he is irregular in his acknowledgment of such exclusions. In more than sixty chapters he gives no indication that his headings overlook significant episodes or events, but in twenty-five others, he gives a final tag to specify just that. These can take various forms, with headings ending "and other incydentes" (1.18), "and of other aduentures" (3.14), "and other thynges" (10.44), and "and of other maters" (18.22). There seems to be no rhyme or reason for why some headings get these tags and others do not, but there is a dense clustering of them in book 17, with ten of the twenty-five tags occurring in that last book of the Grail Quest (which contains only twenty-three chapters). There are an additional six headings with these tags across books 18 and 19, so that roughly two-thirds of the tags appear over these three books. One might account for this by suggesting that these are just event-filled chapters (which they are), but they are not necessarily any more so than many other chapters that do not receive tags. The only suitable explanation is that this is just another idiosyncratic attempt to deal with Malory's fast-paced and episodic text, which adds weight to the suggestion that he was working under no overarching strategy to begin with. Caxton, it seems, was doing the best he could with the time he had, but it is clear that there was no sustained attempt, with such a mammoth undertaking, to regulate, homogenize or even revise his table once he had composed it.

Along with many other things from Caxton and his workshop, Wynkyn de Worde inherited these chapter headings too, with all their peculiarities and idiosyncrasies. But like his master, de Worde exercised a strong editorial hand, and his edition of 1498 (hereafter dW, on which his 1529 edition is closely based), includes a number of crucial changes involving the headings. ${ }^{21}$ Perhaps the least obvious of these are the corrections de Worde

21. Indeed, like Caxton, de Worde considered the chapters and headings his most noteworthy contribution. The colophon to the whole text mentions that the book has been "deuyde[d] 
makes to the content of the headings. These could only have been made by reading through the main text, not just working down through the table. In an important study, Tsuyoshi Mukai noted that de Worde made a sustained effort to identify characters in the main text clearly by correcting wrong names and replacing ambiguous pronouns with names. For Mukai, this sort of emendation is more typical of an editor than a compositor in that an editor would tend to read more closely and comprehensively; for P. J. C. Field, these corrections display "de Worde's characteristic care, thoroughness, and intelligence." ${ }^{22}$ At times, de Worde clears up ambiguities in C's headings, usually by replacing pronouns with proper names, as in the heading mentioned above, book 20, chapter 9 :

Caxton: "Of the sorowe \& lamentacyon for the dethe of hys neuewes \& other good knyghtes / \& also for the quene his wyf"

de Worde: "Of the sorowe and lamentacyon of kynge Arthur for the dethe of hys two neuewes \& other good knyghtes / \& also for the quene his wife"

De Worde also corrects for awkward or convoluted syntax, such as book 7 , chapter 22:

Caxton: "How at nyght cam an armed knyght \& faught with sir gareth \& he sore hurt in the thyghe smote of the knyghtes heed"

de Worde: "How at the nyght came an armed knyght \& faught with Syr Gareth / \& hurted hym sore in the thyge / and how Syr Gareth smote of the knyghts heed"

And he also corrects for occasional errors or omissions, as in book 9, chapter 9:

Caxton: "How Syr Launcelot maad le cote mayle lord of the Castel of Pendragon \& after was made knyght of the rounde table"

de Worde: "How Syr Launcelot maad Le Cote Male Tayle lord of the Castel of Pendragon and after was made knyght of the Rounde Table"

in to .xxi. bokes chapitred. \& enprynt[ed] fyrst by Wylliam Caxton / on who[se] soule god haue mercy. And newel[y] [en]printed. and chapitres of the sam [e] [ru]brisshed at Westmestre by Wynk[yn] [de] Worde." De Worde's 1498 edition of the Noble and Joyous History of the Book Entitled Le Morte Darthur (from colophon) survives only in one near-complete copy (wanting twentytwo leaves), now in the John Rylands Library, 15396. The 1529 edition is housed in the British Library and is available on EEBO, STC 803. In this discussion I will confine myself to the edition of 1498 .

22. Mukai's article persuasively argues that de Worde made use of both C and its copy text, though of course dW's headings derive only from C. See Tsuyoshi Mukai, "De Worde's 1498 Morte Arthur and Caxton's Copy-Text," Review of English Studies 51 (2000): 26; P. J. C. Field, "De Worde and Malory," in The Medieval Book and a Modern Collector: Essays in Honour of Toshiyuki Takamiya, ed. Takami Matsuda, Richard A. Linenthal, and John Scahill (Cambridge: Brewer \& Yushodo, 2004), 291. 
In all, there are twenty-four chapter headings in $\mathrm{dW}$ with changes of this sort, but of course, de Worde was himself not immune to error. ${ }^{23}$ In book 8 , chapter 37 , for instance, he gives the wrong name of the knight whose adventures begin after an interlace division in the text, while Caxton gets it right:

Caxton: "How syr Suppynabyles tolde syr Trystram how he was deffamed in the courte of kyng Arthur / \& of syr Lamerok"

de Worde: "How Syr Suppynabyles tolde Syr Trystram how he was deffamed in the courte of Kyng Arthur / \& of Syr Launcelot"

Such easy slips, though, are likely the work of the compositors, and anyway they are few and far between, so that the overall effect is of a tidier, more error-free table. The tidying, though, took place only on the surface levelmore a series of corrections than revisions-since it is clear is that de Worde did not rewrite the chapter headings with any further concern for the relationship between rubric and text.

But these are the least interesting of the changes that de Worde made to Caxton's headings. The most significant and immediately recognizable change is that de Worde dispersed the chapter headings within the main text, at the heads of their respective chapters. ${ }^{24}$ The effect is major. Rather than the headings being a marketing tool or an index for browsing readers, in $\mathrm{dW}$ they have become integral to the entire reading experience. In C's table, they could be ignored or forgotten if one was reading straight through, or they could have been encountered only intermittently, at the beginning of a stretch of reading (if one was not looking for a particular episode or event). Their influence in $\mathrm{dW}$, though, is much more immediate and sustained, in that their proleptic content becomes a constant if arbitrary conditioning device. For each of dW's chapters, readers are directed to an implied hierarchy of significant events, even though many of those events seem to be selected solely on the basis of their relative distance to the chapter head. The selectivity of many of the headings become all the more important to the reading experience because of their proximity to the text

23. De Worde also corrects for the numbering problems in C. So, for example, when Caxton skips numbers 4 and 5 in bk. 1, de Worde supplies the missing numbers, giving "iij. iv. v" for the third chapter, just as it appears in C's table. The only instance where he does not is bk. 18, chaps. 20-21, where Mukai argues that his edition of $\mathrm{C}$ was missing these pages, or at least they were defective, so that de Worde had to rely on Caxton's copy text. Mukai, "De Worde's 1498 Morte Arthur and Caxton's Copy-Text," 30-31.

24. dW contains both Caxton's prologue and a table, comprising the first two quires. The surviving copy, however, wants leaves $1,4,5$, and 6 of the first quire and leaf 1 of the second. Also, the remaining leaves of the first quire are misbound, and are inserted between the end of the second quire and the beginning of the main text. Thus, in the table, only headings from bk. 8, chap. 32, onward survive. 
they describe, and accordingly because of their greater potential to shape the reception and interpretation of that text. Spisak has argued that the dispersal of headings in dW give them "more weight than Caxton intended them to have." ${ }^{25}$ Extending this, Grimm has also argued that though the Prologue and colophon state explicitly that they are editorial interventions, their placement within dW affords them "authorial weight" with the reader. ${ }^{26}$ It may be that readers never consciously actualize such "weight," but it is perhaps this absorption of the headings into the narrative fabric that makes them so difficult to untangle from the main text in the ordinary reading experience, especially for those headings that mimic the verbal texture of the passages they describe. Placed side by side, the headings and the main text all the more readily confirm each other.

One of the more obvious effects of this dispersal is the immediacy and inescapability of the heading's proleptic content. In a text with so many disguised knights and surprise encounters (so often occurring by "fortune" or "aventure"), knowledge of an armored knight's name or of some future happening can work directly against many of the narrative effects that Malory worked hard to set up. In some cases Malory's romance is internally prognostic, as it is at the end of book 2 when a heading that is proleptic even beyond its own chapter contents does not provide much we could not have surmised already: the final clause of the book 2, chapter 17, heading reads "how Balyn rode towarde a castell where he lost his lyfe." Balin's death does not occur until the end of book 2, chapter 18, so it seems that Caxton himself may have been caught up in the text's own scheme of prophetic foreshadowing. This happens too in book 10, chapters 32-35, where Malory invests a tremendous amount of narrative capital in Anglides's presentation of the bloody doublet to her son Alisaunder le Orphan, and the injunction to revenge that follows. From the moment she keeps the shirt (after her husband's death), to the day Alisaunder is made a knight, the narrative builds to the mother's call for revenge. Again though, Caxton seems to have been caught up in the text's own anticipation, since the heading for chapter 34 tells of the charge given in chapter 35: "How Anglydes gaue the blody doblet to Alysaunder her sone the same daye that he was made knyght / and the charge withal." ${ }^{27}$ The effect in C is of course the same as in $\mathrm{dW}$, if the reader happens to be moving from table to text at precisely this juncture, but in dW the effect is inescapable, since readers

25. Spisak, Caxton's Malory, 2:613.

26. Grimm, "Wynkyn de Worde and the Creation of Malory's Morte Darthur," 136, 142.

27. Though only the "charge" is given in chap. 35. Oddly, W has a red-ink, two-line Lombard separating the presentation of the doublet from the call for revenge (fol. 262v), which Caxton follows in drawing up his division between chaps. 34 and 35, but of course this split is not reflected in the headings. 
would not normally pass over headings located between the chapters. In these sequences, though, what they learn from the headings is really not much more than what they know (or strongly suspect) already.

In many other cases, foreknowledge does alter, or perhaps more accurately, spoil, many of the literary devices central to quest adventure narrative. Take for example book 10, chapter 65, in which Tristram and Palomydes encounter an "armed knight" who challenges them, has his spear taken, but then rides off otherwise unscathed so that "they shold not aske hym his name." Then the two encounter Sir Epynogrys, who calls the unnamed knight the "falsest knyght that bereth the lyf," and only after thirtynine lines in C, and sixty-three in dW, do we learn his name is Sir Brewnys Saunze Pieté, the knight Palomydes hates most in the world. The trajectory of the first two-thirds of the chapter, then, culminates in the moment when we, with Palomydes and Tristram, realize they released the infamous Sir Brewnys Saunze Pieté, whom they had disarmed and could have readily captured. The problem is that the heading gives away the plot. It reads: "How syr Trystram and syr Palomydes mette Breuce sauns pyte and how Syr Tristram and la beale ysoude wente vnto Lonazep." In these masked or mistaken identity episodes, Malory will at times create dramatic irony by allowing the audience to know the identity of the disguised combatants, as in the case of the battle between Arthur and Accolon in book 4, chapters 9-11. But at other times the irony comes later, so that we realize the true nature of events along with with the characters, and thus the suspense is based on who the anonymous knight is, not on whether the characters will recognize each others' true identity before it is too late. The former is the case in book 10, chapter 65, and Caxton's heading is insensitive to the effect Malory works to create.

The same occurs in book 11, chapter 13, when Perceval battles an unidentified knight till they are both mortally wounded; it is only then that they recognize each other and we learn that Perceval was fighting Sir Ectorunless we are reading $\mathrm{dW}$ (or looking to the table in $\mathrm{C}$ ), for the heading reads: "How syr Percyuale mette wyth sir Ector / \& how they faught longe and eche had almoost slayne other." ${ }^{28}$ As with Sir Epynogrys's revelation in book 10, chapter 65, it is only when we arrive at the moment when Ector reveals himself that we realize there is nothing more to the suspense than the revelation itself, and that the heading has spoiled it. At the end of book 11 , chapter 13, and the first half of book 11, chapter 14, we learn just how much of a spoiler the "almost" of the book 11, chapter 13, heading is, since

28. dW gives a slightly altered reading of the final clause: "and how they had almost slayn $e$ eche other." Unusually, dW's heading in the table does not completely accord with the heading in the main text. It reads: "\& how almost they had slayn eche other." It seems both changes were the work of compositors, as neither alters the sense of the heading in C. 
the chapter ends and the next begins with both knights admitting their death wounds. It is only by a miracle of the Grail that they survive, which healing occurs eleven lines from the start of book 11, chapter 14, in C and sixteen in dW. But again the heading of book 11, chapter 14, only confirms and elaborates on the "almost" of book 11, chapter 13, and gives away the resolution of both the chapter and the book: "How by myracle they were bothe made hole by the comyng of the holy Vessel of Sangreal." On the one hand it could be argued that Perceval is too important to die this way on the Grail Quest since he is noted earlier as one of the Grail Knights, but that Ector should be saved is by no means generically necessary, and disrupting expectations is what Malory's Grail Quest does best. Nevertheless, one might say that Perceval is generically "safe" from untimely death in much the same way Gawain is in Sir Gawain and the Green Knight, but possibilities always linger in readers' minds; the heading not only eliminates such possibilities but also spoils the suspense regarding how he might be saved. De Worde never corrects for these spoilers in Caxton's headings, even when his dispersal of the headings through the text intensifies them by making them more immediate and essentially inescapable. If this editorial decision in the 1498 edition gives the headings more influence on the reading experience than Caxton intended them to have, it is surely in these instances where the prolepsis works against Malory's literary designs that such influence is most forcefully and disruptively felt.

I have noted earlier that de Worde will occasionally revise the chapter headings to clear up ambiguities or correct errors. His most sustained reworking of Caxton's headings, though, was of the book headings. Of the twenty-one book headings in $\mathrm{C}$, de Worde makes changes to nine of them; all of these changes are additions, where de Worde amplifies the content of C's headings by adding adjectives (italics indicate de Worde's additions):

Book 1: "The fyrst boke shall entreate how Uterpendragon gat the noble $\mathcal{E}$ myzty conqucrour kynge Arthur. and conteyneth .xxviii. chapytres"

Book 2: "The seconde boke treatyth of Balyn the noble and valyaunt knyghte. and conteyneth .xix. chapytres,"

or details of either knights' names or their quests,

Book 14: "The fourtenth boke treatith of the queste of the sancgreall / E specyally of the actes of syr Percyuale de Galys in the queste of the Sancgreall. \& conteyneth .x. chapyters"

Book 15: "The fyftenth boke treatyth of syre Launcelot in the queste of the Sancgreall. \& conteyneth .vi. chapyters." 29

29. Only once does de Worde correct for awkward syntax in the book headings. Compare the second clause of C, "The xiii book treateth how galahad came fyrst to kyng Arthurs courte 
As in C, these headings are found only in the table, and thus it seems probable that de Worde is using such amplification for advertising purposes, especially when one considers that prospective buyers may well have been more inclined to look closely at the twenty-one book headings and only breeze through those of the individual chapters, if they looked through them at all.

Puzzling, though, is the question of why de Worde did not disperse these newly revised book headings within the main text. A look to the beginnings of each of the books reveals some peculiar details. The first page of each book contains a woodcut illustration (on which more below) taking up roughly half the page. Below that in books 1-9 is a book heading in a type twice the size of the main text. The heading of the first book doubles as a heading for the whole work, but books 2-9 simply give "Here foloweth the .ii. [.iii., .iiii., etc.] booke of that noble prynce kyng Arthur" (see fig. 1). ${ }^{30}$ This is then followed by the heading for the first chapter, in the same type as the main text, and a six-line woodcut capital to begin the chapter. The heading for book 10 is different: "Here begynneth the seconde boke of Syre Trystram. \& the .x. boke of this present volume" (see fig. 2). And in books 1121 the headings are dropped altogether, so that the headings for each of the books' first chapters double as the headings for the books themselves, set as they are in the larger type used for the book headings in 1-10 (see fig. 3).

The most likely explanation for this roughly even split in terms of bibliographic strategies is that de Worde had two compositors working on the project, and he gave books 1-9 to one and 10-21 to the other. Book 9 ends on a recto with the corresponding verso left blank, the only instance of a blank page in the volume, suggesting the split in labor occurs between 9 and $10 .^{31}$ There are a few possible ways to account for the idiosyncrasy of the book 10 heading. One possibility could be that compositor B made an exception in his usual practice for the sake of clarification, since the division splits the two longest books in the work and both of them focus on Sir Tristram. Another could be that this is just an idiosyncrasy of the first book $\mathrm{B}$ sets, and that he is loosely following (though not replicating) C. Though most of C's books are bracketed with incipits and explicits, book 10 is the

and the quest how the sangreall was begonne and conteyneth xx chapytres," with that of dW, "The thyrtenth boke treatyth how syr Galahad came fyrste to kyng Arthurs court. and how the queste of the Sancgreall was begonne. and conteyneth .xx. chapytres."

30. The heading for bk. 1 reads, "Here begynneth the fyrst boke of the noble kyng. kyng Arthur. sometyme kynge of Englonde and of his noble actes and feates of armes of chyualrye \& his noble knyghts \& table rounde. and is deuyded in to .xxi. books."

31. Grimm also makes this observation, though he adds that A gives a uniform heading for bks. 2-9 to further what Grimm considers one of the primary intentions of the table: to invoke the centrality of Arthur. See Grimm, "Wynkyn de Worde and the Creation of Malory's Morte Darthur," 149. 


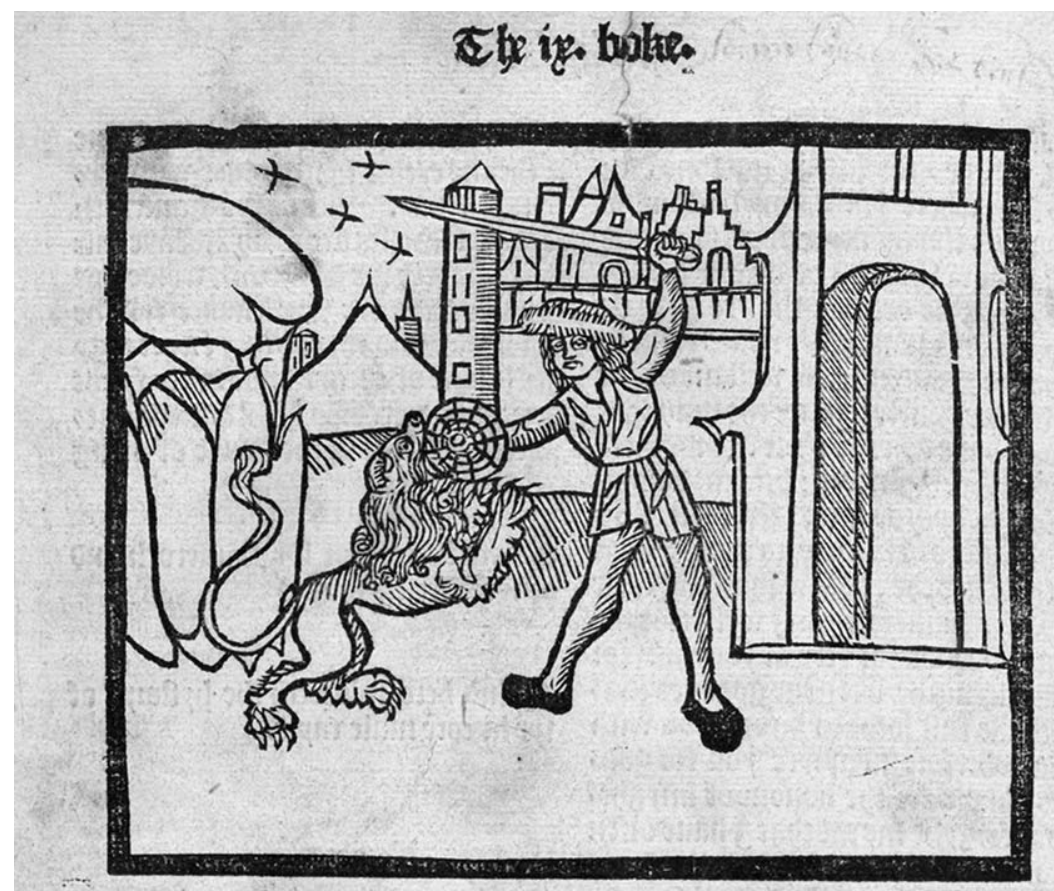

T5ate foloweth the .ix. Loo, he of that noble pepnte tronis 2litthur.

If fow a yonge man came in to the court of lapng Zltthur/\& bow [pr Rzap calleo bpin in fcome la cote male taple caplin primũ.

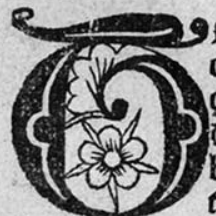
Prece came to the cout of kyng Altbur a yon' ge man e bpggelp ma oc/ano be was rpechelp bplene/ano be oefprea to be made knpglbt of the hing / but bis ouer garment latte ouerty wartly bow be it / it was ryche dotbe of golde. What is your name fayo kpng Zltthur. Spr Lapo bempna ne is sievenor le nopre / and within Chorte [pace pe fhall knowe that $\mathcal{T}$ an of gooo kynne. Sft map well be tapo fpr Lzap the feneldball/but in mocka; ge ye thall be calleo la cofe male taple that is as moche to tape the eupll tha pen cote. St is a urete thpuge that $\ddot{\$}$ afket fapo the kyng. Ino for what caufe werelt thoul that tuche cote/felle me /for $\mathcal{I}$ can wel tbpribe for fome cau fe it is. Sye be anfwered J bao a fader a noble knpght/e as be rode on buns tynge bpoy a oape, ibit happeo bpm ta Ipe bym douin to flepe. Ano there came a knoght $\$$ bad ben longe bis enempe Ano nobain be fave be woas faft on fle pe be all to bewe bym/ano tbis fame

Figure 1. "Here foloweth the .ix. booke of that noble prynce kyng Arthur." From Le Morte d'Arthur, ed. Wynkyn de Worde (Westminster, 1498). Reproduced by courtesy of the University Librarian and Director, The John Rylands Library, The University of Manchester. 


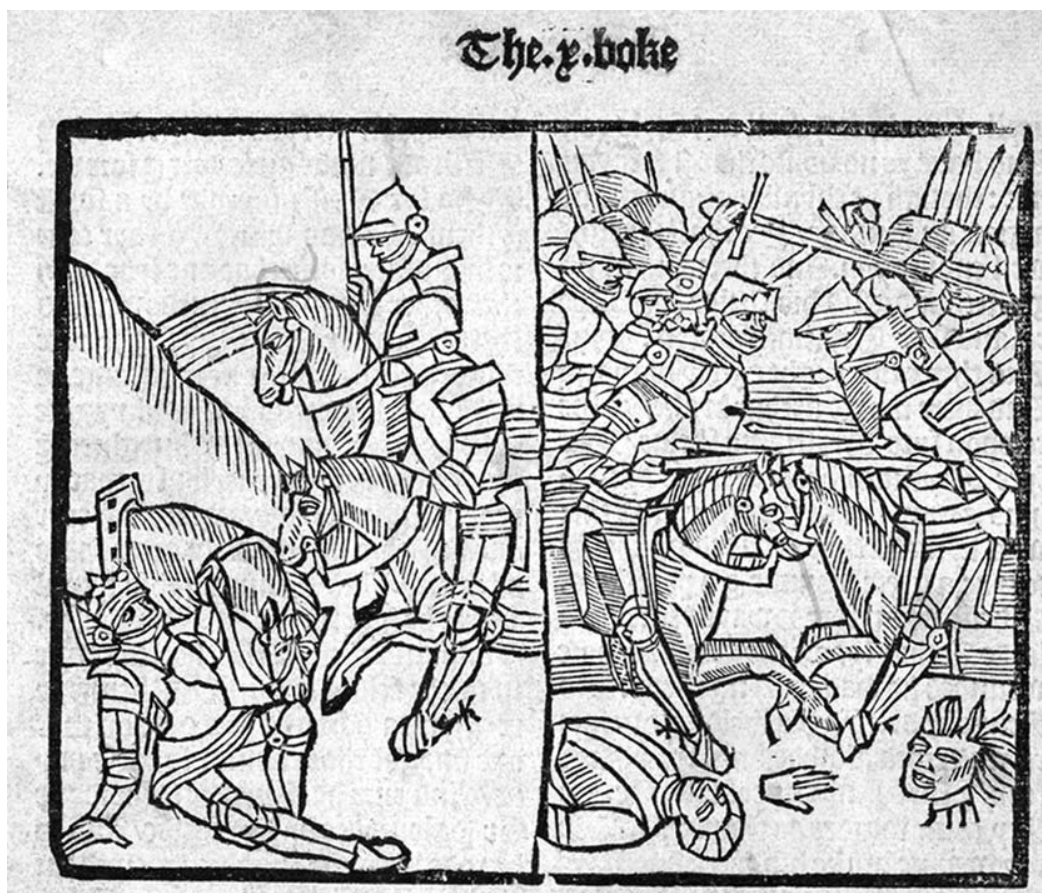

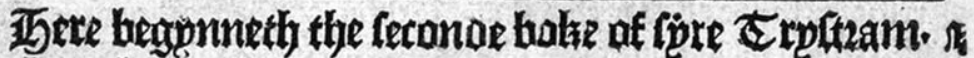
the ce.hotre of this pefent uolume .

If fow lpe cruftam ioulted e Imo te Downe kpnge Altbur e [pr SD way ne e woloe not telle tberm bis name I Iapitulum primum

Genue fapo Zutbur / yf to be pe cay optexy ue what ye beeze / ye are wortby to bete $\dot{p}$ armes. Els for that la po [pre c tuftram 3 woll antwere pou/chps fbeloe was peuen me not oefpico of qnene ST) 02 " gay le fay/ Zlno as for tme $\mathcal{J}$ can not opfezpue thyfe armes /for it is no pos ynt of my charge/ Ano yet 7 tutte to goo to bere tbem woytb worthíp. Cru In Lapae kzpnge Althus/pe ougbt not to beete none atmes / but yf ye woplte what pe barc/ 2 but 7 praye you telle me your name/ Co what entent lap oe \{pre Cruftranj/ for $\mathcal{I}$ woloe wopte fapo Zatbut. Spre pe chall not wopte as at'tbis thme/Cbey fbal pe e J do bataple togyoers fayo kpnge Zirtbur Dobp tapo fpre Cruttam/woll pe do batapll woptb me but of $\mathcal{J}$ fell poump name and tbat lptpll neditb pou e pe were a mav of worlbpp / for pe baue baue feen me this dap bao gaete tha"

a $i$

Figure 2. "Here begynneth the seconde boke of Syre Trystram. \& the .x. boke of this present volume." From Le Morte d'Arthur, ed. Wynkyn de Worde (Westminster, 1498). Reproduced by courtesy of the University Librarian and Director, The John Rylands Library, The University of Manchester. 


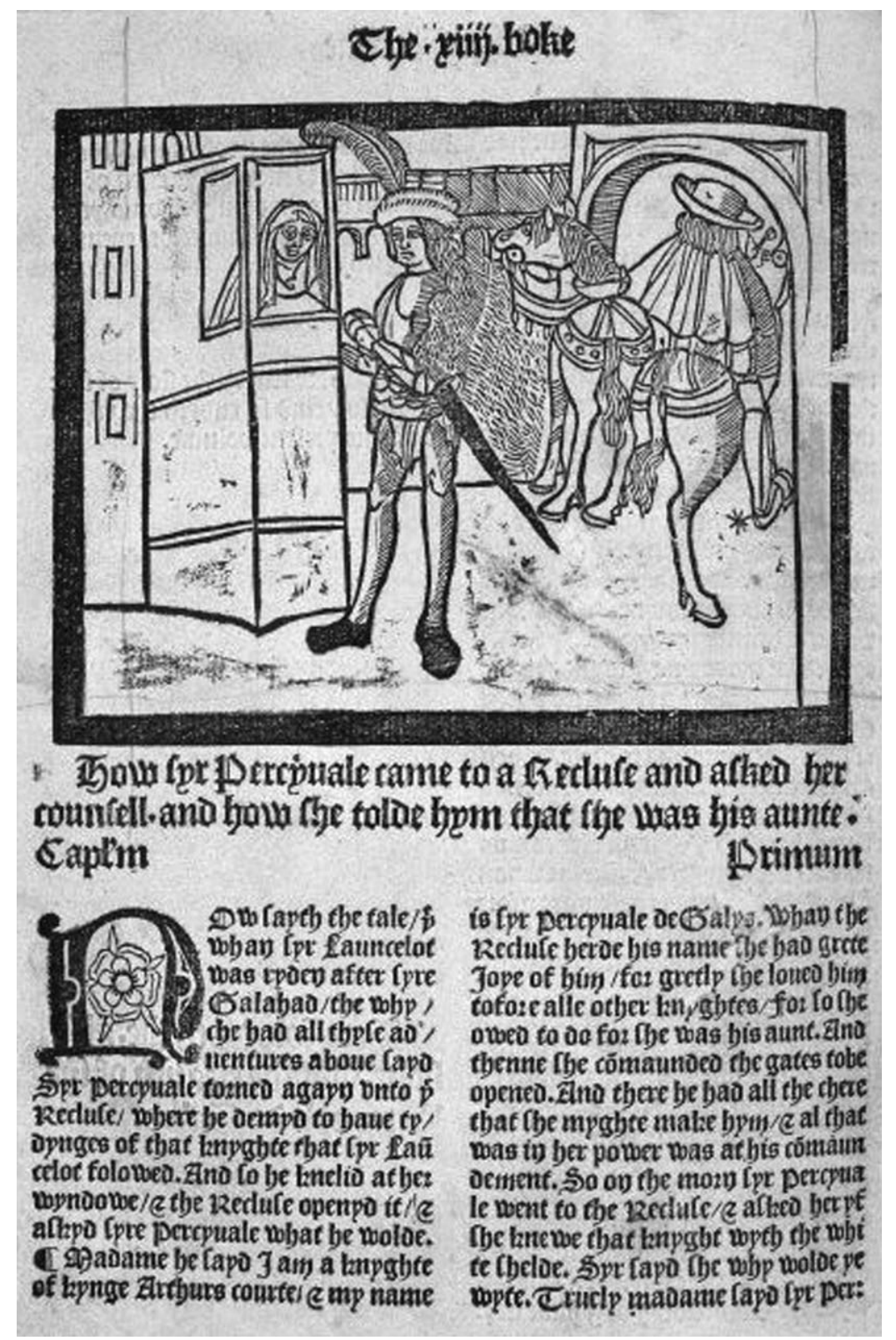

Figure 3. Book 14: "How syr Percyuale came to a Recluse and asked her counsel. and how she tolde hym that she was his aunte." From Le Morte d'Arthur, ed. Wynkyn de Worde (Westminster, 1498). Reproduced by courtesy of the University Librarian and Director, The John Rylands Library, The University of Manchester. 
only one with a descriptive heading (perhaps included for the same reasons just mentioned).$^{32}$ It is possible, too, that book 10 was designed to soften the transition from the practices of $\mathrm{A}$ to $\mathrm{B}$, perhaps being reset once the two compositors compared notes. But this points to conclusions we can make about overarching editorial practices. The lack of uniformity between the two halves suggests that A and B were essentially left to their own devices when it came to certain aspects of the volume's apparatus, while other details such as the double columns, the running headers, and the six-line woodblock capitals remain consistent across the two compositors. Also, the fact that neither A nor B use the book headings from the prologue, which de Worde had deliberately reworked for amplification, also suggests that de Worde did not set out a homogenous strategy for dealing with the book divisions. There is no way of knowing whether de Worde had revised these headings before the compositors set to work, but in any case C's book headings would have been a logical and uniform source for the headings in the main text of $\mathrm{dW}$.

Such an apparent lack of editorial oversight, suggestive of a certain lack of concern with the uniformity of the text's bibliographic components, is all the more surprising when we consider the woodcuts. These woodcuts, Edward Hodnett tells us, are unique among books printed before 1535, since $\mathrm{dW}$ is the only edition of an English literary work from that period with an original series of interpretive illustrations. ${ }^{33}$ The text contains twentyone illustrations, one at the head of each book, with the exception that the same woodcut is used for books 20 and 21, and the final woodcut appears at the beginning of book 21, chapter 4, depicting the final battle on Salisbury plain. Especially with prints for romances, a genre with a propensity for repetition, generic (appropriate but not specific) woodcuts are the norm, but here nineteen are "direct" illustrations, in that each depicts a particular textual moment. ${ }^{34}$ The other two (books 10 and 11), made by a different artist, are generic illustrations and, as Hodnett notes, they were the only woodcuts from dW subsequently used to illustrate more than two other titles. Of the nineteen direct woodcuts made by the primary cutter, eleven were used only

32. The heading in C reads: "Here begynneth the second book of sire Tristram / How syre Tristram smote doune kyng Arthur \& sir Vwayne / by cause he wold not telle hem wherfor that shelde was made / But to say the sothe sire Tristram coude not telle the cause / for he knewe it not." There is no way of knowing whether Caxton or a compositor composed this heading, but Caxton's heading for bk. 10, chap. 1, in the table cuts out the extraneous "sir Vwayne" and the final aside "But to say the sothe"; it reads: "How syr Trystram iusted and smote doun Kyng Arthur / by cause he tolde hym not the cause why he bare that shelde."

33. Edward Hodnett, Image and Text: Studies in the Illustration of English Literature (London: Scolar, 1982), 5 .

34. See Ruth Samson Luborsky, "Connections and Disconnections between Images and Texts: The Case of Secular Tudor Book Illustration,” Word and Image 3 (1987): 74-75. 
to illustrate editions of the Morte Darthur, their specificity making them very expensive indeed. ${ }^{35}$ Why then, if de Worde is so invested (artistically and economically) in providing fitting illustrations for the first page of each book, does he not lay out the particulars of these pages for his compositors? Perhaps a modern editor's concern with homogeneity would have been foreign to de Worde and his contemporaries (as seems to have been the case), and perhaps too, what interested him were only the illustrations themselves. 36

For our purposes, a more interesting question is what events or episodes the nineteen specific images represent. The answer is simple but its implications are significant: in all cases they refer to events that happen in the first or second chapters of their books. At a meta level, then, the woodcuts are as front-end heavy as many of the chapter headings, and the effect is that they give emphasis to the events that occur in the first chapters of each book rather than to the most important or interesting events in the books overall. At times it could be argued that these coincide, as in book 4 when Merlin is shut away for good inside a rock (fig. 4), but this is more the exception. In most instances first chapter events would not rank high on a scale of significance, as in book 14 where the woodcut depicts Perceval meeting his aunt, the recluse (fig. 3). As figure 3 shows, an effect of the front-heavy reference of the woodcuts, combined with B's use of the first chapter headings to double as book headings, is that these headings now function as both descriptions of their chapters and as captions for the woodcuts. With this woodcut and caption combination, readers are faced with two complementary levels of interpretive conditioning before they even arrive at the chapter's first line.

It might be argued that something similar happens in books 2-9 in that the narrative tags are not descriptive and the link between woodcut and first chapter heading is often obvious (see, e.g., fig. 4). But in some instances there is an uneasy correlation between woodcut and chapter heading. A good example is the first chapter of book 9 (fig. 1), where, as mentioned earlier, Caxton describes only the chapter's first events at the expense of ignoring the more exciting battle later in the chapter between La Cote Male Tayle and the lion. What this exposes is the interpretive work that goes into the creation of both the woodcut and the heading, and how readers must negotiate that interpretive conditioning as they use the apparatus to prepare for and later reflect on the text itself. What these incongruities between

35. See Edward Hodnett, English Woodcuts, 1480-1535 (Oxford University Press, 1973), 14; Martha W. Driver, "The Illustrated de Worde: An Overview," Studies in Iconography 17 (1996): 349-403.

36. Indeed, as Henry Plomer notes, "The outstanding feature of de Worde's work was his love of pictures. He seldom, if ever, let a book go without one" (Wynkyn de Worde and His Contemporaries from the Death of Caxton to 1535 [London: Grafton, 1925], 61); see also Driver, "Illustrated de Worde," 363. 


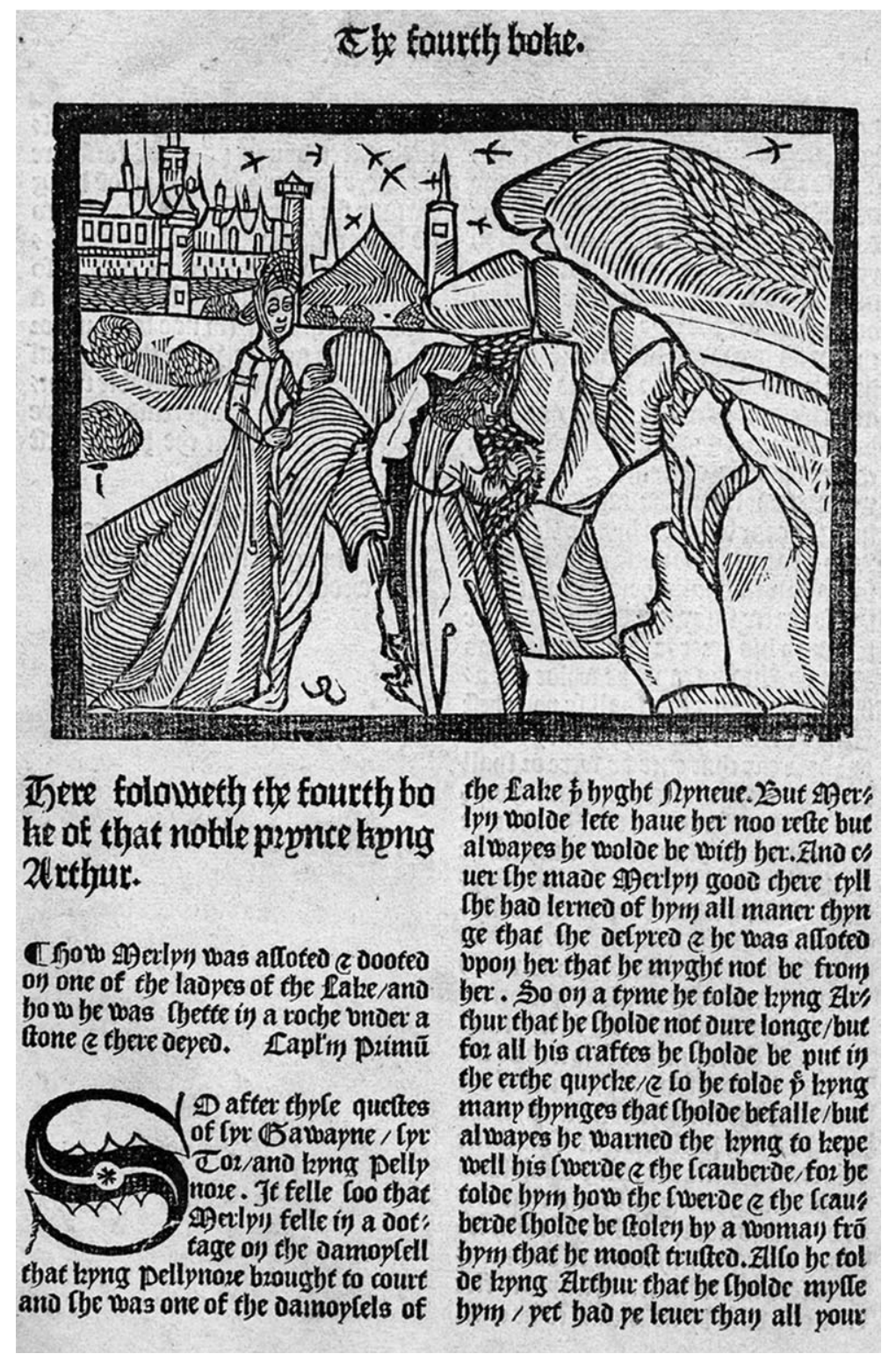

Figure 4. "How Merlyn was assoted \& dooted on one of the ladyes of the Lake / and how he was shette in a roche vnder a stone \& there deyed." From Le Morte d'Arthur, ed. Wynkyn de Worde (Westminster, 1498). Reproduced by courtesy of the University Librarian and Director, The John Rylands Library, The University of Manchester. 
woodcut and heading suggest, too, is something of the engagement of the woodcut artist (or those who gave him instruction). Once the plan was set to depict references from the first chapter of each book, it would have been easy to draw straight from those books' headings. But this did not happen. Instead, the artist chose to depict an episode that would better lend itself to visual representation: the battle with the lion. Even when the woodcut depicts the same event as the heading describes, the artist will often include details not described in the heading, so that the artist or his instructor would have had to work through the chapter itself to devise a plan for the illustration. For book 8 (fig. 5), for instance, the woodcut depicts a scene immediately after Tristram's birth, when he is named "sorowfull byrth," and then his mother's death, both mentioned in the heading: "How syr Trystram de Lyones was borne and how his moder deyed at his byrth / wherfore she named hym Trystram." But the artist would have had to consult the chapter itself to include details such as the forest setting, the "gentylwoman" who presents the baby to the mother before she dies so that she might name him, and then her immediate death before anyone else arrives (which happens at the beginning of the next chapter). This relationship between woodcut, heading and text works both ways, for readers have to read the entirety of the first chapter to realize that the woodcut presents a sequence depicting the final two clauses of the heading (given there in reverse order), in which Tristram is named and then Elizabeth dies, rather than a single scene of two nurses with the baby Tristram after the death of his mother.

As the case of book 8, chapter 1 , shows, the form of de Worde's edition, made up of a combination of bibliographic elements, can have a significant influence on the reading experience. In its worst moments it can spoil the drama that Malory's text works to generate; at other times it can produce expectations that will blossom in the reading of the text. One would like to think that the readers of the 1498 Morte Darthur would move backwards as well as forwards in the reading process, examining the illustrations with the knowledge that the text provides, feeling the significance of those images changing with that new knowledge. Moments such as these show the genius of de Worde as an innovator who spared no expense to enrich the experience of his readers. Of course, in this he takes his cue from his master Caxton, whose own efforts to create chapters for Malory's romance, and then headings for those chapters, changed the way readers thought about the Morte Darthur for hundreds of years. Even now, when the unity debate still smolders, the editorial decisions both Caxton and his successor made have stood the test of time. True, the woodcuts have all but vanished (aside from Spisak's edition), but other features, including the chapters and their headings, have survived even the discovery of the Winchester manuscript; they have become part of the modern reading experience of Malory's massive, complex, magnificent romance. 


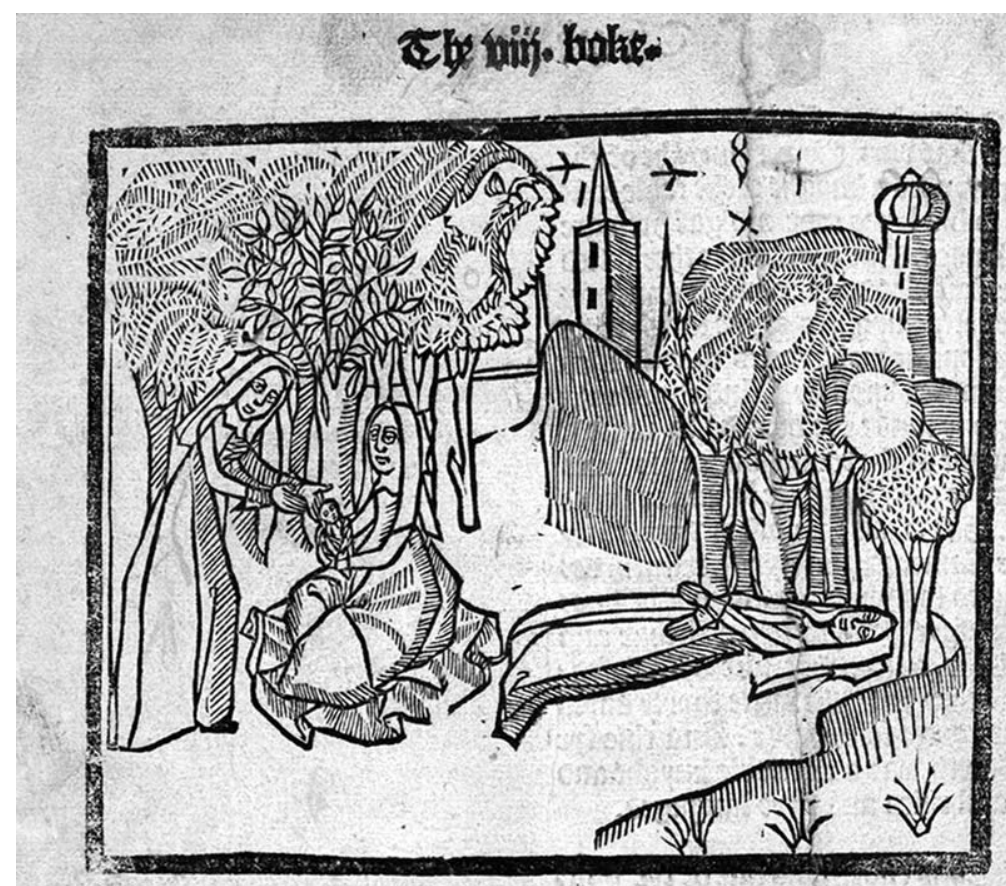

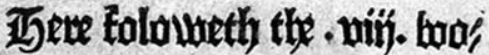 the of that nobile pepnce tipng 2utthux.}

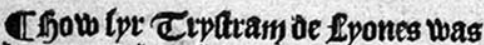
boune and bow bis moder oeped at bis betb, whetfoxe the namea bym ety" (train. ICapl'm Drimú.

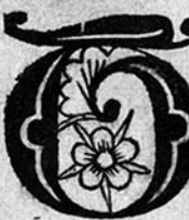

Qfiete was a kpng that bpgbt 2 felpodas/c be was lozoe e kpng of the countree of IPones. e this $\mathfrak{A}$ elyooas was a lphelp knpabt asonp was that tpme lpupnge. Ano bp fortus ne be weoded byng ingarkes fpeter of
Ifornetwaple. Ano te was calleo Elip sabeth that was caleo both good and fapre. Eno at that wre kyng Zlthut tegneo / c be was lole hyng of IEngs lonoc. Maales ano scotlonoe/ano of manp otber ropanes/bow be it thete. were mant livnoes that wete lozes of many conttees/bufall they beloe thept lonoes of kyng Zitbur. for in 1oales were two kpnotes/and in the flouth wete many bynes / ano in Iornes waple $z$ in the llet wete two hpnges allo in Sorlonie wete two on there byr ges/and all wore bnoet the obeptauis, re of bong Zftisur/ 2 fo was the bpng of firaunce ane the kpno of Soptap" te and all the lo:olhpppes bnto rome Soo whan this lapnge SHelpodas bad bet) cetapy tyme with bis wop/witbin

Figure 5. "How syr Trystram de Lyones was borne and how his moder deyed at his byrth / wherfore she named hym Trystram." From Le Morte d'Arthur, ed. Wynkyn de Worde (Westminster, 1498). Reproduced by courtesy of the University Librarian and Director, The John Rylands Library, The University of Manchester. 